\title{
HLA-linked control of the course of M. leprae infections
}

\author{
RRP de VRIES, W van EDEN \& JJ van ROOD
}

Dept. of Immunohaematology, University Medical Center, Leiden, the Netherlands

\section{Introduction}

The only simple discovery in leprosy has probably been made more than a century ago. It is clear from the disease spectrum that the modulation of the host response to the lazy Mycobacterium has to be a complicated matter. That genetic host factors play a role was already realized before Hansen (1). Probably the best and certainly easily presentable evidence for an important role of genetic host factors comes. from twin studies conducted by Chakravartti and Vogel only about 10 years ago (2). Table 1 shows that monozygotic twins show a much higher concordancy not only for leprosy, but also for

Table 1. Genetic host-factors in leprosy: twin studies.

\begin{tabular}{|l|cc|} 
& both leprosy & \\
& type $=$ & type $\neq$ \\
\hline monozygotic twins $(\mathrm{n}=62)$ & $32(52 \%)$ & $5(8 \%)$ \\
dizygotic twins $(\mathrm{n}=40)$ & $6(15 \%)$ & $2(5 \%)$ \\
\hline
\end{tabular}

(from: Chakravartti and Vogel 1973)

leprosy type.

There are two important reasons why a study of the HLA system in relation to the disease spectrum in leprosy a priori seemed worth while. In the first place, the HLA system shows more than enough variation to be a good candidate for an important and therefore probably complicated host factor. In the second place, products of the HLA system have been shown to be involved in the immune response and in particular in the interaction between $\mathrm{T}$ cells and macrophages (3) supposed to be of crucial importance in the host defense against Mycobacterium leprae (4). 


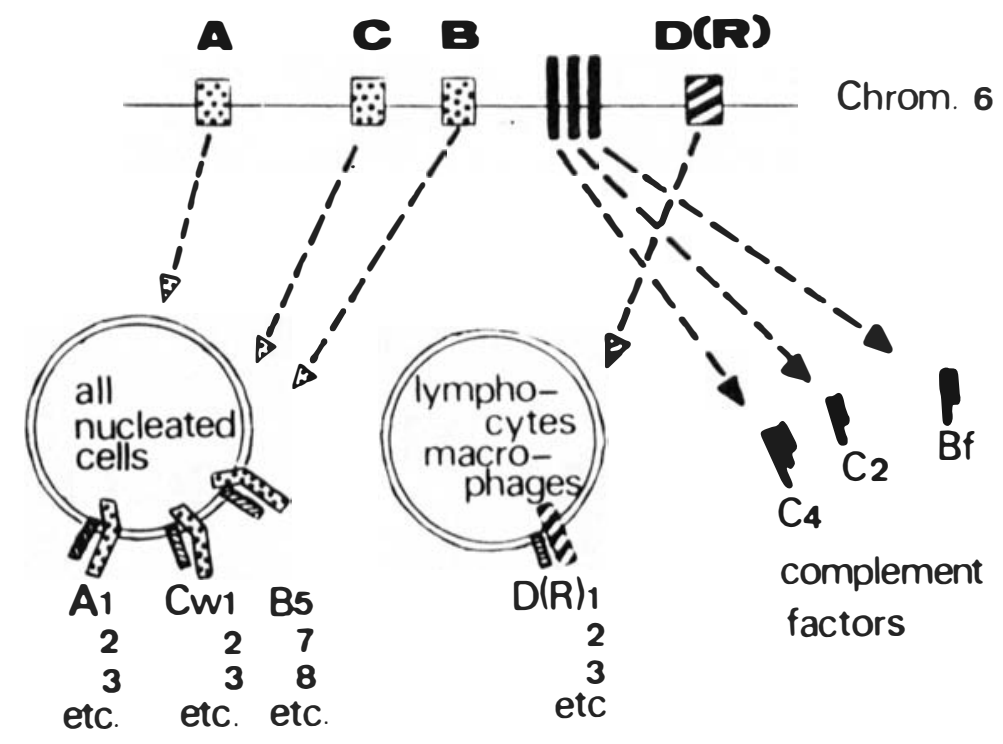

Figure 1 illustrates some important aspects of the HLA system and its gene products. At least 7 loci have been defined, where the genes are located coding for 3 types of molecules. The first type is present on most if not all nucleated cells and is coded for by genes situated at three loci: HLA-A, -B, and $-C$. Every determinant is identified by a number (e.g. A1). If this definition is not yet optimal, the number is preceded by the prefix "w" (e.g. Cw1). A second type of determinants is also situated on the cell membrane, but has a restricted tissue distribution. This type II determinant is seen preferentially on lymphocytes (mainly B lymphocytes, but also activated $\mathrm{T}$ lymphocytes) and macrophages. Originally these determinants were defined by cell culture methods (mixed lymphocyte cultures), but more recently this is also possible with serological techniques. Although there are probably more loci containing genes coding for these determinants, thus far only one locus has been well defined: HLA-D, or -DR, if we mean the serologically defined determinants. Finally a number of factors of the serum complement system are coded by genes located in HLA: C2 and C4 of the classical and factor $B(B f)$ of the alternative pathway.

Both type I molecules (HLA-A, $-B$, and $-C$ ) and type II molecules (HLA-D, -DR) are very polymorphic: about 20 different HLA-A determinants (or alleles), $40 \mathrm{HLA}-\mathrm{B}, 8 \mathrm{HLA}-\mathrm{C}$, and $10 \mathrm{HLA}-\mathrm{D}(\mathrm{R})$ determinants are known. The complement factors show a much lesser degree of polymorphism. Every individual has 2 copies of chromosome 6 and therefore 2 HLA-A, -B etc. determinants, which because of this high polymorphism will often be different. The complexity of the HLA 
system is illustrated by a comparison with the ABO system: in the ABO system there is one locus with 3 alleles and 6 different genotypes, whereas the HLA system has at least 7 loci with more than 90 determinants and more than $40 \times 10^{6}$ possible combinations.

The distance between the different HLA loci is very small: only in about one out of 100 meioses a cross-over occurs. The information for the different HLA determinants on one chromosome, or haplotype, is therefore nearly always inherited as such. Every individual has 2 HLA haplotypes, which can lead to 4 different combinations, if he or she marries and gets children. One in 4 children will therefore be identical for HLA. Unrelated individuals have of course a much smaller chance to be HLA identical if we think of the enormous number of possible combinations. It appears however that some combinations occur much more frequently than expected on the basis of the respective gene frequencies. This phenomenon is called linkage disequilibrium and is illustrated in figure 2.

Figure 2. Linkage disequilibrium (A1-B8-DRw3); 75 DRw3 positive haplotypes on HLA-A versus HLA-B. (from Lamm et al. 1977)

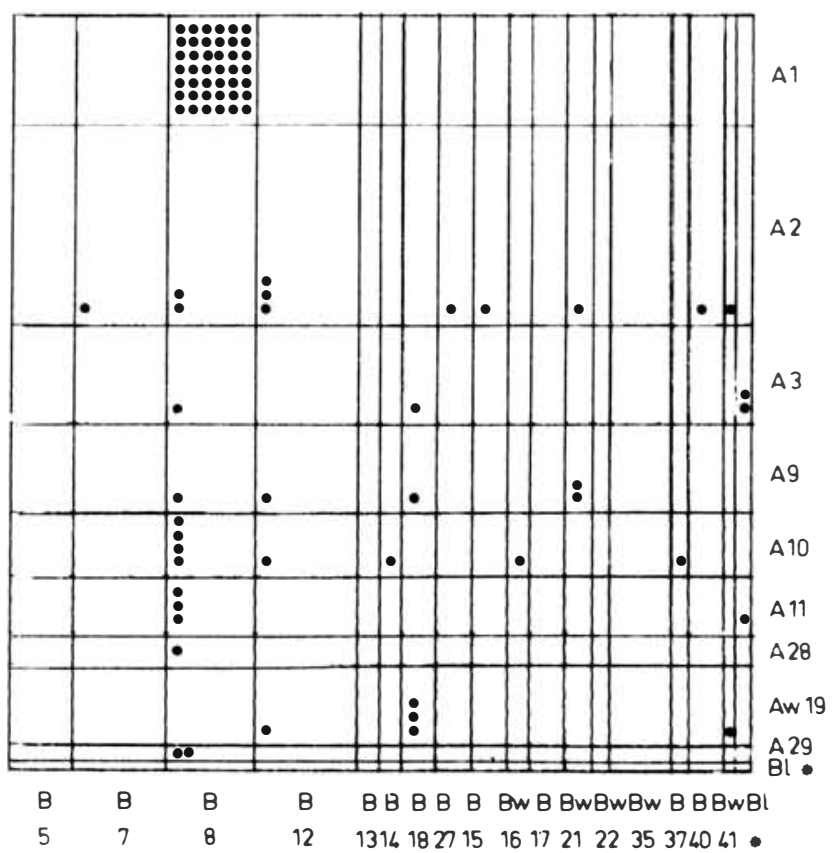

It is quite possible that individuals carrying these preferential combinations have had a better chance to survive infectious diseases in the past (4). It should be noted that there is a great variation both of gene frequencies and linkage disequilibria between different populations.

In the present context, we will confine ourselves to mention only one functional aspect of the products of HLA, which is probab- 
ly the most pertinent with respect to leprosy. The type II molecules, that is HLA-D(R), are crucial in the interaction between $T$ cells and macrophages (3). This is illustrated in figure 3 for the response to PPD.

Figure 3. PPD responses of allogeneic T lymphocyte/macrophage combinations expressed as relative antigen-specific stimulation (RAgS). The ranges and medians are given. Note that for an adequate response, $\mathrm{T}$ lymphocyte and macrophage donors must share at least one HLA-D antigen. (from Bergholtz and 'I'horsby 1977)

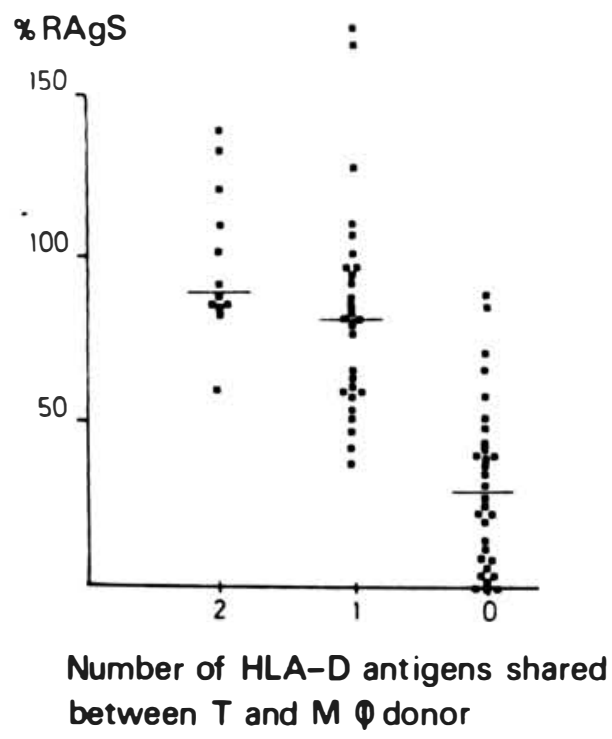

Some general methodological comments on HLA and disease studies

When looking for a possible relationship between HLA and a disease, two different approaches have been used: a population study or a family study. In a population study we look for an association between a particular HLA type and a disease, which may be due to either causation (that is the associated antigen itself is responsable for the higher or lower susceptibility) or linkage disequilibrium of a susceptibility gene with the associated HLA marker. For the basically simple protocol, the statistics and pitfalls of these studies, the interested reader is referred to svejgaard et al. (6). Family studies have two big advantages compared with population studies: 1 ).

lation heterogeneity and 2) they do not rely on linkage disequilibrium. Of course a third important aspect of family studies is, that they may provide extra genetic information, such as the inheritance, penetrance and frequency of disease susceptibility genes. Apart from the fact that appropriate families are often difficult to collect, a methodological problem is that familial cases of a 
given disease may not be representative of the patient population. The statistics of these family studies basically concern the question: do affected siblings more often than expected share HLA haplotypes?

HLA-A, -B, - C and leprosy: population studies

We know of 16 publications addressing the question of a possible association between HLA-A, $-B$, and/or $-C$ antigens and leprosy or leprosy-type (7-22). Before attempting to draw general conclusions from these studies a few comments seem useful. In the first place, the leprosy classification varies from study to study. Furthermore these studies often concern small patient samples or small samples from certain subgroups. Sometimes there have been clear technical problems in HLA typing (8), and in general the investigators did not use the same typing reagents. All these factors make comparisons and interpretation a difficult task. Perhaps the most important methodological criticism is, that often not enough care seems to have been taken in matching of the control group. Probably just the healthy donors or staffmembers of the HLA typing center often do not represent a well matched control group. This is elegantly shown for instance by Smith et al. (11).

With these considerations in mind, we choose not to make an extensive analysis of all positive and negative data, but rather to see whether there might be a pattern in the positive results.

\begin{tabular}{|c|c|}
\hline \begin{tabular}{c|} 
HLA \\
antigen
\end{tabular} & $\begin{array}{c}\text { Antigen freq. in patients vs controls } \\
\mathrm{T}\end{array}$ \\
\hline 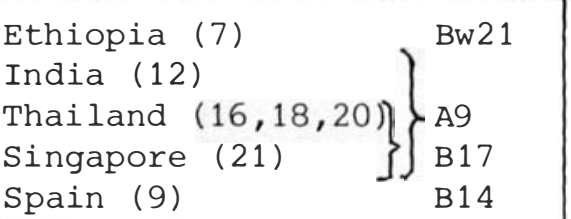 & $\begin{array}{l}\uparrow\left(R R^{X}=?\right) \\
\downarrow(R R=0.4) \\
\uparrow(R R=3.2) \\
=\end{array}$ \\
\hline $\begin{array}{l}{ }^{\mathrm{x}} \mathrm{RR}=\text { Relative risk }=\text { how ma } \\
\text { occurs amongst individuals } \\
\text { those without it. In this } \mathrm{f} \\
\text { not occur amongst healthy } \\
\text { theoretically the } \mathrm{RR} \text { is inf }\end{array}$ & $\begin{array}{l}\text { Y times more frequently the disease } \\
\text { arrying the antigen as compared to } \\
\text { rticular case the Bw } 21 \text { antigen did } \\
\text { ntrols (and LL patients) so that } \\
\text { nite. }\end{array}$ \\
\hline
\end{tabular}

Table 2 shows the associations, which were either confirmed in other studies (A9 and B17), or significant after correction for the numbers of comparisons made and not disproved by later studies (which were simply not performed to our knowledge: Bw21 and B14). If we then try to draw some general conclusions, we could state the following:

The fact that only 7 out of the 16 studies are listed means that a lot of studies were negative or not confirmed. 
With one exception (9) the associations are with tuberculoid leprosy. It is perhaps interesting that in spain the ratio tuberculoid versus lepromatous leprosy is 1:2.5, whereas in the other studies this ratio is $\geqslant 1: 1$. Another exception might be Japan with a $\mathrm{T}: \mathrm{L}$ ratio of $1: 3$, where no significant differences in HLA antigen frequencies might be found between tuberculoid and lepromatous leprosy, but both differing from healthy controls (Isumi et al., personal communication). The Relative Risk (see note to Table 2), for the confirmed associations is in the order of 3 , which means that it is certainly not an "all or none" phenomenon.

The fact that associations with different HLA antigens are found is most easily explained by assuming that the associations are nót due to causation but most probably due to linkage disequilibrium of the associated antigen with leprosy susceptibility genes. It was stated earlier that there is marked inter-population variation in linkage disequilibria. This logically led us to family studies.

\section{Family studies}

Because the detection of linkage in family studies does not rely on linkage disequilibrium, these studies seemed most appropriate to test whether the assumption, that the associations found were due to linkage disquilibrium of the associated HLA antigen and a leprosy susceptibility gene was correct. As far as we know 6 family studies were performed (23-28), of which 3 by the same group, namely ourselves $(23,25,27)$. The positive results of these studies are shown in Table 3 .

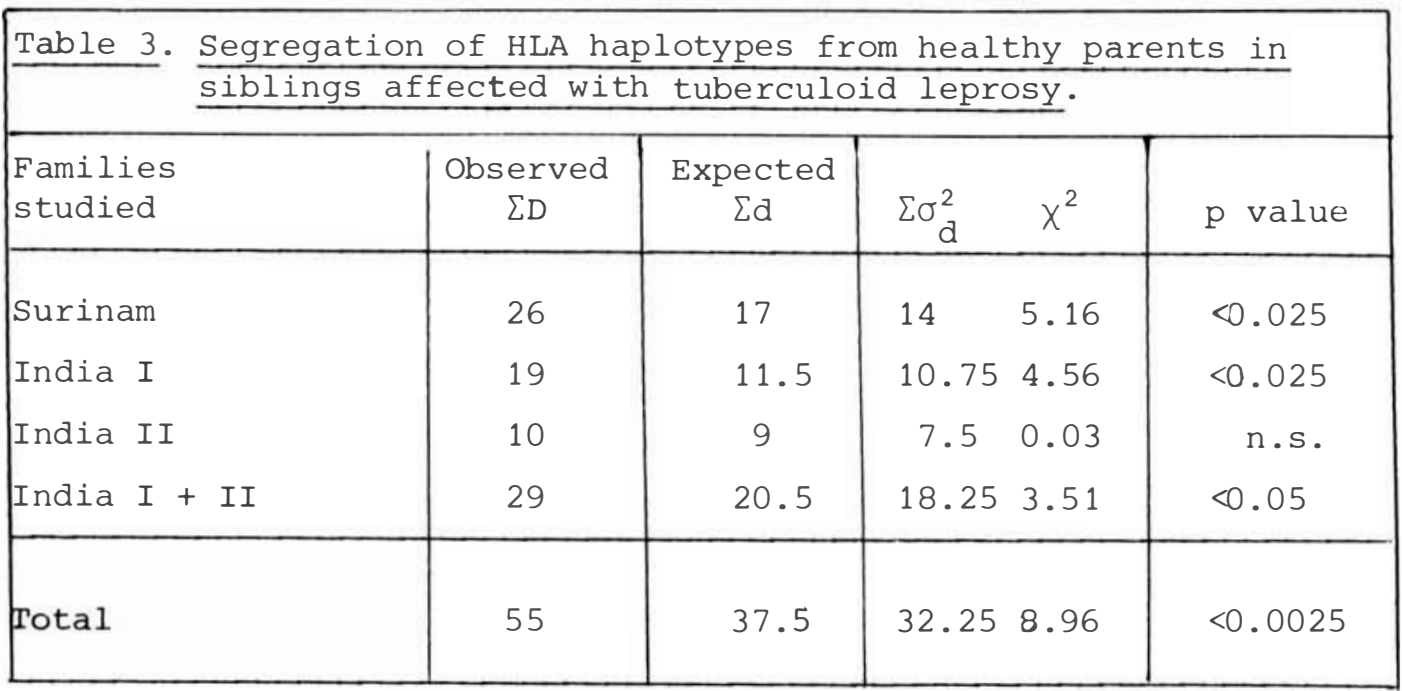

The conclusions from these 3 studies were a) that (a) gene(s) conferring susceptibility to tuberculoid leprosy is linked to HLA 
and b) that the data best fitted with a recessive inheritance. This was confirmed in a large study by Fine et al. (26), that is only evidence for susceptibility to tuberculoid leprosy being linked to HLA and again suggestion for recessive inheritance. Not easily explainable by us is the observation in the latter study that the data were only significant in families, where both parents were healthy. A study of one 3 generation family in Brasil (28) is compatible with these data. A study by stoner et al. (24) used a quite different protocol, but is a confirmation of our and Fine's negative results, namely that no evidence was found for linkage of susceptibility to lepromatous leprosy with HLA.

Associations with HLA-DR?

As stated earlier it was expected for functional reasons, that stronger associations than with HLA-A, $-\mathrm{B}$, and $-\mathrm{C}$ might be found with HLA-DR (3). The first indication, that this might indeed be the case came from our family studies in India $(25,27)$, where no evidence for an association of tuberculoid leprosy with a particular HLA-A, -B, or -C antigen was found, but a significant association with HLA-DR2. Moreover, a preferential segregation of HLA-DR2 from healthy parents to children affected with tuberculoid leprosy could be shown in the first study (25) and confirmed in the second family study (27). Table 4 shows the combined data of the two studies.

Table 4. Inheritance of DR2 haplotypes by the children affected with tuberculoid (T) leprosy of each DR2 heterozygous parent (27).

\begin{tabular}{|c|c|c|c|c|c|}
\hline Families ${ }^{x}$ & Parents & $\begin{array}{l}\text { Children } \\
\text { DR2 } \\
\text { inherited }\end{array}$ & $\begin{array}{l}\text { ith } \mathrm{T} \text { leprc } \\
\mathrm{DR} 2 \text { not } \\
\text { inherited }\end{array}$ & $x^{2 *}$ & $\mathrm{p}$ \\
\hline India I & $\begin{array}{l}\text { Healthy } \\
\text { All not affected } \\
\text { with } T \text { leprosy }\end{array}$ & $\begin{array}{r}8 \\
11\end{array}$ & $\begin{array}{l}3 \\
3\end{array}$ & $\begin{array}{l}2.27 \\
4.57\end{array}$ & $\begin{array}{l}0.013 \\
0.03\end{array}$ \\
\hline India II & $\begin{array}{l}\text { Healthy } \\
\text { All not affected } \\
\text { with } T \text { leprosy }\end{array}$ & $\begin{array}{l}12 \\
12\end{array}$ & $\begin{array}{l}1 \\
5\end{array}$ & $\begin{array}{l}9.31 \\
2.88\end{array}$ & $\begin{array}{l}0.002 \\
0.09\end{array}$ \\
\hline India $I+I I$ & $\begin{array}{l}\text { Healthy } \\
\text { All not affected } \\
\text { with } T \text { leprosy }\end{array}$ & $\begin{array}{l}20 \\
23\end{array}$ & $\begin{array}{l}4 \\
8\end{array}$ & $\begin{array}{r}10.67 \\
7.26\end{array}$ & $\begin{array}{l}0.001 \\
0.007\end{array}$ \\
\hline
\end{tabular}

${ }^{x}$ Data from India $I$ is from (25) and from India II is from (27). India I + II represents data that were combined from the two studies.

Numbers in these columns refer to number of DR segregations, not to numbers of children.

* Calculated for deviation from expected 1:1 ratio. 
Of course we then performed a population study to test whether this association could also be shown in non-familial cases. To our disappointment no association with HLA-DR2 (nor any other HLA antigen) could be shown for tuberculoid leprosy patients without family members known to be affected with leprosy (van Eden et al., Tissue Antigens in press). Although not expected, this negative result in our mind is interesting.for epidemiologists, because it suggests a different epidemiological situation for familial and "sporadic" tuberculoid leprosy.

Also unexpected was that in two absolutely different populations an association with HLA-DR2 was reported, namely in Mexican Indians (29) and in Japan (Isumi et al., personal communication). In Japan the association was not only with tuberculoid but also with lepromatous leprosy (see also the paragraph on HLA-A, -B, -C population studies). This might indicate, that HLA-DR2 itself might be responsible for the increased susceptibility to (tubercliloid) leprosy.

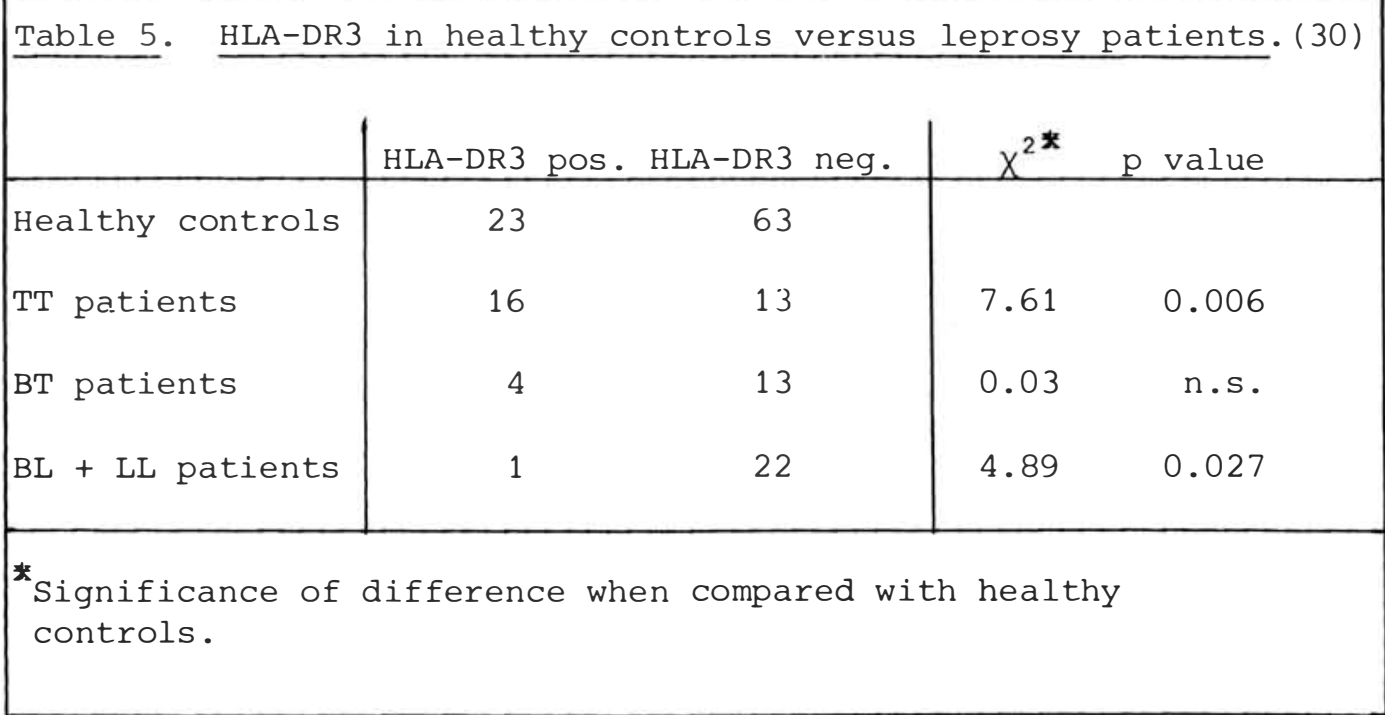

That this does not seem to be the case, at least not in every population, is shown by the interesting results of a recent study conducted among Surinam people shown in Table 5 and graphically illustrated in figure 4. This study most clearly suggests, that the association is not with susceptibility to leprosy, but rather with the response to the bacillus. 
Figure 4. Relative risks to develop different types of leprosy for Surinam individuals carrying HLA-DR3 as compared to those lacking this determinant (30).

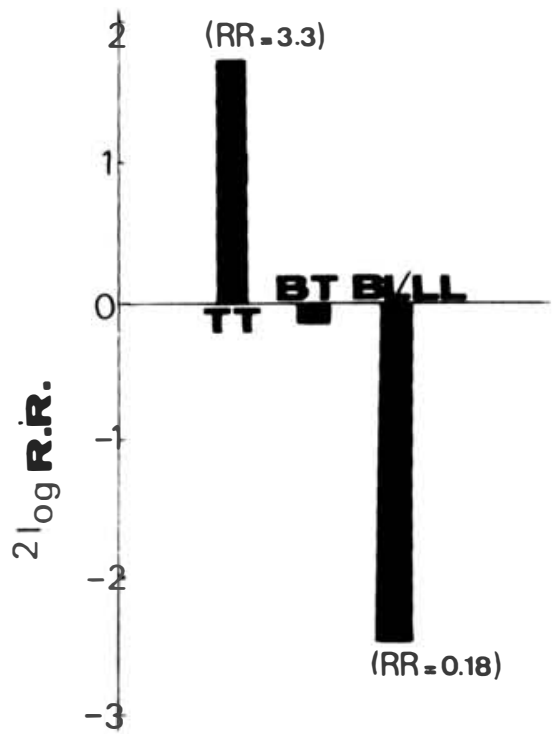

General conclusions

The genetic factors controlling the course of M.leprae infections are not simple, not confined to HLA, and probably different and/or differently modulated by environmental factors in different populations.

As far as HLA-linked factors are concerned: most evidence exists regarding the development of tuberculoid leprosy. This means that individuals prone to develop tuberculoid leprosy may be genetically different from those, who stay healthy after exposure to the bacillus. We realize that this is not in keeping with the ideas many epidemiologists have on tuberculoid leprosy.

It seems that the HLA-linked factor(s) do not confer susceptibility to infection, but rather modulate the type of immune response to M.leprae. This is similar to observations in mice for other intracellular growing bacteria, such as Listeria and Leishmania, where the susceptibility to infection is not, but the development of specific immunity is linked to $\mathrm{H}-2$, the equivalent of the HLA system in the mouse $(31,32)$. 
References

1 Spicket SG. Genetic mechanisms in leprosy. In Cochrane RG, Davey

$\mathrm{TF}$, eds. Leprosy in Theory and Practice, second edition.

Bristol: John Wright, 1964, 98-124.

2 Chakravartti MR, Vogel F. A Twin Study on Leprosy. In Becker PE et al., eds. Topics in Genetics. Stuttgart: Thieme Verlag, 1973, I , 1-123.

3 van Rood JJ, de Vries RRP, Bradley BA. Genetics and Biology of the HLA System. In Dorf ME, ed. The Role of the Major Histocompatibility Complex in Immunobiology. New York: Garland STPM Press, 1980, 59-113.

4 Godal T, Myrvang B, Stanford JL, Samuel DR. Recent advances in the immunology of leprosy with special references to new aspects in immunoprofylaxis. Bull Inst Pasteur, 1974, 72, 247-310.

5 de Vries RRP. The HLA System and Infectious Diseases. The Hague, Pasmans, thesis, State University of Leiden, 1977.

6 Svejgaard A, Jersild C, Staub Nielsen L, Bodmer WF. HLA-A Antigens and Disease. Statistical and Genetical Considerations. Tissue Antigens, 1974, 4, 95-105.

7 Thorsby E, Godal T, Myrvang B. HL-A antigens and susceptibility to diseases. II. Leprosy. Tissue Antigens, 1973, 3, 373-377.

8 Escobar-Gutiérrez A, Gorodezky C, Salazar-Mallén - M. Distribution of some of the HL-A system lymphocyte antigens in Mexicans. Vox Sang, 1973, 25, 151-155.

9 Kreisler M, Arnaiz, A, Perez B, Fernandez Cruz E, Bootello A. HLA antigens in leprosy. Tissue Antigens, 1974, 4, 197-201.

10 Reis AP, Maia F, Reis VF, Andrade IM, Campus AAS. HL-A antigens in leprosy. Lancet, 1974, II, 1384.

11 Smith GS, Walford RL, Shepard CC, Payne R, Prochazka GJ. Histocompatibility antigens in leprosy. Vox Sang, 1975, 28, 42-49.

12 Dasgupta A, Mehra NK, Ghei SK, Vaidya MC. Histocompatibility antigens (HL-A) in leprosy. Tissue Antigens, 1975, 5, 85-87.

13 Rea $\mathrm{TH}$, Levan NE, Terasaki P. Histocompatibility Antigens in Patients with Leprosy. J Inf Dis, 1976, 134, 615-618.

14 Mehra NK, Dasgupta A, Ghei SK, Nilikanta Rao MS, Vaidya MC. HLA Antigens and Leprosy. Microbios letters, 1976, 3, 79-83.

15 Nakajima S, Kobayashi S, Nohara M, Sato S. HLA antigens and susceptibility to leprosy. Int J Lepr, 1977, 45, 273-277.

16 Youngchaiyud U, Chandanayingyong D, Vibhatavanija T. The incidence of HLA antigens in leprosy. Vox Sang, 1977, 32, 342-345.

17 Takata H, Sada M, Ozawa S, Sekiguchi S. HLA and Mycobacterial infection: increased frequency of B8 in Japanese leprosy. Tissue Antigens, 1978, 11, 61-64.

18 Greiner J, Schleiermacher E, Smith T, Lenhard V, Vogel F. The HLA system and leprosy in Thailand. Hum Genet, 1978, 42, 201-213.

19 Massoud A, Nikbin B, Nazari GR, Syadat NA, Ala F. A study of cell mediated immunity and histocompatibility antigens in leprosy patients in Iran. Int J Lepr, 1978, 46, 149-153. 
20 Chiewsilp P, Ashkambhira S, Chirachariyavej T, Bhamavapravati N, Entwistle C. The HLA antigens and leprosy in Thailand. Tissue Antigens, 1979, 13, 186-188.

21 Chan SH, Oon BB, Kamarudiu A, Wee GB. HLA and leprosy in Chinese. Tissue Antigens, 1979

22 Mohagheghpour N, Tabatabai H, Mohammad K, Ramamunjam K, Modabber FZ. Histocompatibility antigens in patients with leprosy from Azerbaijam, Iran. Int J Lepr, 1979, 47, 597-600.

23 de Vries RRP, Lai A Fat RFM, Nijenhuis LE, van Rood JJ. HLAlinked genetic control of host response to Mycobacterium leprae. Lancet, 1976, II, 1328-1330.

24 Stoner GL, Touw J, Belehu A. In-vitro lymphoproliferative response to Mycobacterium leprae of HLA-D identical siblings of lepromatous patients. Lancet, 1978, II, 543-547.

25 de Vries RRP, Mehra NK, Vaidya MC, Gupte MD, Meera Khan P, van Rood JJ. HLA-linked control of susceptibility to tuberculoid leprosy and association with HLA-DR types. Tissue Antigens, $1980,16,294-304$.

26 Fine PEM, Wolf E, Pritchard J, Watson B, Bradley DJ, Festenstein $\mathrm{H}$, Chacko CJG. HLA-linked genes and leprosy: a family study in a South Indian population. J Inf Dis, 1979, 140, 152-161.

27 van Eden W, de Vries RRP, Mehra NK, Vaidya MC, D'Amaro J, van Rood JJ. HLA segregation of tuberculoid leprosy: confirmation of the DR2 marker. J Inf Dis, 1980, 141, 693-701.

28 Lawrence DN, Bodmer JG, Bodmer WF. Distribution of HLA antigens in Ticuna Indians of Brazil: Results of typing a leprosyaffected family. Tissue Antigens, 1980, 16, 152-160.

29 Rea TH, Terasaki PI. HLA-DR antigens in tuberculoid and lepromatous leprosy. Lepr Rev, 1980, 51, 117-123.

30 van Eden $W$, de Vries RRP, D'Amaro J, Schreuder I, Leiker DL, van Rood JJ. HLA-DR associated genetic control of the type of leprosy in a population from Surinam. Submitted for publication.

31 Skamene E, Kongshaven PAL, Sachs DH. Resistance to Listeria monocytogenes in mice: genetic control by genes that are not linked to the H-2 complex. J Inf Dis, 1979, 139, 228-231.

32 Blackwell J, Freeman J, Bradley D. Influence of $\mathrm{H}-2$ complex on acquired resistance to Leishmania donorani infection in mice. Nature, 1980, 283, 72-74. 